\title{
Nutrient Composition of Spotted Knapweed (Centaurea
} maculosa)

\author{
RICK G. KELSEY AND ROBERT D. MIHALOVICH
}

\begin{abstract}
Spotted knapweed (Centaurea maculosa Lam.) is a noxious plant that has invaded many native ranges and open woodlands of western Montana. Knapweed is generally considered to have a low palatability to domestic livestock and wildlife, but local ranchers have observed sheep, goats, and some cattle ingesting large quantities of fresh knapweed during the spring and knapweed silage and hay during the winter. Nutrient analysis of plants collected prior to nowering showed neutral detergent fiber at 24.2 to $53.0 \%$ (dry wt.), ether extract 3.1 to $9.0 \%$, crude protein 6.2 to $18.2 \%$, total nonstructural carbohydrates 11.0 to $27.5 \%$, ash 4.9 to $9.3 \%$, in vitro dry matter digestibility 53.2 to $61.8 \%$, and gross energy 4,088 to 4,539 cal/g. Crude protein and nonstructural carbohydrates were most concentrated during the spring growth period when stems were developing. As the stems matured during summer they became more fibrous resulting in lower protein and carbohydrate levels. Just prior to flowering, tall plants with stems approaching $1 \mathrm{~m}$ had significantly higher fiber, but lower ether extract, carbohydrates, and in vitro dry matter digestibility than plants with stems less than $0.5 \mathrm{~m}$. Crude protein, ash, and gross energy were the same for both groups. It was concluded that spotted knapweed does have some nutritional value as a livestock forage. Spring grazing of knapweed or harvesting for $a$ winter forage may be useful in the control of this noxious plant.
\end{abstract}

Key words: Centaurea maculosa Lam., weed control, noxious plants, neutral detergent fiber, crude protein, total nonstructural carbohydrates, in vitro digestibility.

Spotted knapweed (Centaurea maculosa Lam.) is a Eurasian native found in most northern U.S. states and provinces of Canada (Reed and Hughes 1970, Moore 1972, Watson and Renney 1974). Introduced to the Pacific Northwest region around the turn of the century, Maddox (1979) estimated 842,000 ha of spotted knapweed in the 3 states of Montana, Idaho, and Washington. Over 800,000 ha occur in western Montana and it is spreading at an annual rate of approximately $27.4 \%$ (Lacey 1983 ). Initially considered only a rangeland problem, it is aggressively penetrating openings in forest habitats (Spoon et al. 1983).

As the density of knapweed increases, the productivity of the desirable forage plants decreases drastically, $40-80 \%$ or greater (Watson and Renney 1974, Harris and Cranston 1979, Maddox 1979). Annual revenue losses in Montana from the current level of infestation are estimated at $\$ 4.5$ million (French and Lacey 1983). On forested land the infestation is beginning to affect the growth and survival of shrubs and young trees (Spoon et al. 1983). Dense stands lower the recreational quality of a site and they detract from the aesthetics, particularly along forest roads and trails.

Livestock consumption of spotted knapweed has been consi-

\footnotetext{
Authors are research associate professor, and former research assistant, Department of Chemistry, University of Montana, Missoula 59812. The current address for senior author is Entomology Department, Oregon State Universty, Corvallis 97331 .

The research was supported by a grant from the McKnight Foundation, Minneapolis, Minn., and by the University of Montana. This paper is dedicated to the memory of Professor Melvin S. Morris

The authors thank Dr. Keith Osterheld for allowing us to feed his cattle knapweed silage, Dr. Jim Cox who let us feed his sheep silage and hay, Dr. N. Stark who conducted the mineral analysis, and Dr. Kris Havstad at Montana State University for the measurement of in vitro digestibility. We thank Mr. Mark Bjorlie and Robert Davis for their assistance in the laboratory, and all those individuals who shared their observations of livestock use on knapweed.

Manuscript accepted 2 January 1987.
}

dered minimal, especially mature plants because of their high fiber content and low nutritive value (Watson and Renney 1974, Maddox 1979, Strang et al. 1979). In 1983, Cox reported sheep eating large quantities of knapweed in the spring and early summer when the plants are succulent and actively growing. Not only did sheep eat it, but they preferentially selected the knapweed over grasses as long as the knapweed was abundant. Spoon et al. (1979) concluded that sheep prefer knapweed and that goats eat it along with other forage. They also reported significant early/mid season use by some cattle in western Montana. This raised questions about knapweed's nutritional content. In this paper we report selected nutrient components of spotted knapweed from populations in western Montana.

\section{Methods and Materials}

\section{Plant Samples}

In 1984 plant samples were collected from 4 sites in the vicinity of Missoula, Mont. All were within Township 13 North and Range 19 West. Site 1 was sampled on 31 May and 2 August. This population was located on a vacant lot surrounded by commercial property. The soil surface had an abundance of sawdust and woody residue. Plants were large with mature stems reaching $1.0-1.5 \mathrm{~m}$ in height. Because of slower growth, sites 2,3 , and 4 were sampled initially on 12 June and again on 2 August. These were more typical of rangeland populations with mature stem heights ranging from 0.2 to 0.8 $\mathrm{m}$. Samples were sealed in plastic bags, and placed on ice for transport to the laboratory. Two different samples were collected at site 1 during August: regrowth from plants that had been mowed earlier in the year for silage and mature plants that had received no previous treatment.

\section{Solvent Extraction}

Fresh tissues from May/June collections were treated as follows. Moisture content was measured in triplicate subsamples by oven drying at $100^{\circ} \mathrm{C}$. Three fresh samples, $50 \mathrm{~g}$ each, were extracted with $500 \mathrm{ml}$ of solvent; the first was extracted with chloroform for 5 minutes, the second with $95 \%$ ethanol for $30 \mathrm{~min}$, and the third with distilled water overnight $(15 \mathrm{hr})$. They were air-dried after extraction.

Several hundred grams of fresh tissue was placed in a $100^{\circ} \mathrm{C}$ oven for $10 \mathrm{~min}$ to stop metabolic activity, then air-dried. Three air-dried samples from each site, with a dry weight equivalent to 50 $\mathrm{g}$ of fresh tissue, were extracted like the fresh samples. A dried sample from each population was used as an unextracted control. All samples were ground to particle sizes specified for analysis, oven-dried $\left(65^{\circ} \mathrm{C}\right)$, and sealed in screw cap vials until needed.

\section{Silage and Hay}

Approximately $180 \mathrm{~kg}$ of knapweed were cut with a mower at a site 1 on 31 May and again on 13 June 1984. The chopped tissue was packed into plastic bags and tightly sealed for ensilaging. On 2 August a sample of each silage was air-dried and prepared like the other samples for analysis. Knapweed hay was obtained from a local rancher who had cut and baled the plants during the first 2 weeks in August 1984. Random samples from 6 bales were ground and mixed into a single sample. 


\section{Plant Samples}

Between 28 June and 2 July plant samples were collected from 2 separate populations at each of 7 locations in western Montana (Somers, Polson, Missoula, Stevensville, Darby, Drummond, Superior). The first 5 sites were located along a north/south line approximately 175 miles long. Superior and Drummond were 50 miles west and east of this line, respectively. The 2 populations at each location were selected by plant height, one representing tall plants with stems approaching $1 \mathrm{~m}$ and the other representing short plants with stems less than $0.5 \mathrm{~m}$. In general the tall plants were growing on sites that had been rangeland, dry pasture, or grazeable woodlands, but where the soils had been severely disturbed by man and his activities, along the edge of gravel roads, and open lots associated with, or influenced by, commercial development. Short plants grew on rangelands and dry pasture where soils appeared less disturbed and possibly more harsh, hotter, drier, or with fewer nutrients in the soil. At each population 30 stems were measured for length; the nearest stem was measured every $30 \mathrm{~cm}$ along a $9-\mathrm{m}$ line transect. For nutrient analysis 1 or more stems were clipped near ground level every $1.5 \mathrm{~m}$ along this same tape. In the short plant populations it was necessary to cut numerous plants at each point in order to obtain sufficient tissue. These stems were combined in a plastic bag and returned on ice to the laboratory. All plants were rinsed with cold water to remove loose dust, then clipped into small pieces and placed into a $100^{\circ} \mathrm{C}$ oven for $45 \mathrm{~min}$. The tissue was transferred into paper bags to oven dry $\left(65^{\circ} \mathrm{C}\right)$. After grinding and redrying $\left(65^{\circ} \mathrm{C}\right.$ for $\left.24 \mathrm{hr}\right)$, samples were sealed in screw cap vials and stored in a desiccator until needed.

\section{Chemical Analysis}

The nutrient analysis included crude protein (\% nitrogen by microKjeldahl $\times 6.25$ ), ether extract ( 4 hours extraction instead of 16), ash, and gross energy as described by Harris (1970), neutral detergent fiber (Goering and Van Soest 1970), and total nonstructural carbohydrates (daSilveira et al. 1978). Each composite sample was analyzed in duplicate. For mineral analysis $0.5 \mathrm{~g}$ of $60 \mathrm{mesh}$ tissue was ashed $\left(500^{\circ} \mathrm{C}\right.$ for $\left.2.5 \mathrm{hr}\right)$. After cooling, the ash was moistened with deionized water, covered with $10 \mathrm{ml}$ of aqueous $\mathrm{HCl}$ (1:1), and gently boiled to reduce the volume about one-half. This was diluted to $50 \mathrm{ml}$ and analyzed by inductively coupled plasma spectroscopy using a Jarrell-Ash AtomComp Model 865. Dry matter digestibility was determined in triplicate using Barnes modification of the Tilley and Terry technique (Harris 1970). Cnicin, a bitter tasting sesquiterpene lactone located in glandular trichomes on the epidermal surface of spotted knapweed, was quantificd by high performance liquid chromatography (Marchand et al. 1983, Locken and Kelsey in press).

\section{Data Analysis}

Data for spring vs. summer plants in 1984 and tall vs. short plants in 1985 were analyzed by a one-way analysis of variance. Prior to analysis the percentage data were transformed to get homogeneity in variances.

\section{Results}

In the spring of 1984 when the stems of spotted knapweed were succulent and actively growing, the nutrient content of this tissue was comparable to native forage plants and appears adequate to meet livestock needs (Table 1) (Ensminger and Olentine 1978). Plants from the 3 upland sites had 9-10\% crude protein compared to $18.2 \%$ at site 1 . Woody organic matter on the soil surface was apparently supplying nutrients for the latter. All of the other components were quite similar between the 4 populations. By early August, approximately 2 to 3 weeks after the onset of flowering, the fiber content had nearly doubled, causing decreases in all the other components, particularly the crude protein (Table 1). The ether extract was least affected, with increases at 2 sites. Gross energy was higher for all plants in the summer. Regrowth from plants cut in May/June for silage was less fibrous and had lower cnicin concentrations compared to those left untreated. Protein and carbohydrates were slightly higher in the regrowth while ash and ether extractables were similar to the quantities in untreated plants.

Solvent extractions had essentially the same effect on fresh and dried samples; therefore, only the data for dried tissues are presented in Table 2. Chloroform and ethanol gave nearly identical results; they removed $50 \%$ or more of the ether extractables and 74 to $90 \%$ of the cnicin, with almost no change in any of the other substituents (Tables 1 and 2). Chloroform was more efficient at removing cnicin. Water extracted soluble minerals and carbohydrates, concentrating all of the other components in the tissue.

Spring knapweed plants and the silage from site 1 had a chemical composition comparable to alfalfa silage and hay (Tables 1 and 3). The knapweed hay was very stemmy and fibrous, with a low

Table 1. Nutrient composition and cnicin concentrations of spotted knapweed collected at 4 sites in the Missoula valley during the spring and summer of 1984.

\begin{tabular}{|c|c|c|c|c|c|c|c|c|}
\hline \multirow[b]{2}{*}{ Sample description } & \multicolumn{7}{|c|}{ \% Dry Weight } & \multirow[b]{2}{*}{$\begin{array}{r}\text { Gross } \\
\text { energy } \\
(\mathrm{cal} / \mathrm{g})\end{array}$} \\
\hline & $\begin{array}{c}\text { Neutral } \\
\text { detergent } \\
\text { fiber }\end{array}$ & $\begin{array}{l}\text { Ether } \\
\text { extract }\end{array}$ & $\begin{array}{c}\text { Crude } \\
\text { protein }\end{array}$ & $\begin{array}{c}\text { Total } \\
\text { nonstructural } \\
\text { carbohydrates }\end{array}$ & Ash & Cnicin & Other & \\
\hline \multicolumn{9}{|l|}{$\overline{\text { Site } 1}$} \\
\hline May & 24.2 & 3.1 & 18.2 & 24.9 & 9.3 & 0.53 & 19.8 & 4093 \\
\hline Aug. untreated & 50.7 & 3.7 & 9.4 & 16.7 & 5.2 & 0.68 & 13.6 & 4436 \\
\hline Aug. regrowth & 33.3 & 3.4 & 13.4 & 18.7 & 5.7 & 0.41 & 25.1 & 4362 \\
\hline \multicolumn{9}{|l|}{ Sites $2-4$} \\
\hline June & $\begin{array}{l}26.7 \\
(0.6)^{1}\end{array}$ & $\begin{array}{c}5.7 \\
(1.8)\end{array}$ & $\begin{array}{c}9.2 \\
(0.4)\end{array}$ & $\begin{array}{l}25.4 \\
(1.8)\end{array}$ & $\begin{array}{l}7.7 \\
(0.5)\end{array}$ & $\begin{array}{c}1.18 \\
(0.54)\end{array}$ & $\begin{array}{l}24.1 \\
(2.5)\end{array}$ & $\begin{array}{r}4195 \\
(61)\end{array}$ \\
\hline Aug. & $\begin{array}{l}45.5 \\
(4.9)\end{array}$ & $\begin{array}{c}4.3 \\
(1.0)\end{array}$ & $\begin{array}{c}5.2 \\
(0.4)\end{array}$ & $\begin{array}{l}19.0 \\
(1.1)\end{array}$ & $\begin{array}{l}5.2 \\
(0.3)\end{array}$ & $\begin{array}{c}0.54 \\
(0.08)\end{array}$ & $\begin{array}{l}20.2 \\
(4.2)\end{array}$ & $\begin{array}{r}4332 \\
(25)\end{array}$ \\
\hline \multicolumn{9}{|l|}{ Mean } \\
\hline May/June & $\begin{array}{l}26.1 \mathrm{a}^{2} \\
(1.3)\end{array}$ & $\begin{array}{r}5.0 \mathrm{a} \\
(1.9)\end{array}$ & $\begin{array}{r}11.5 \mathrm{a} \\
(4.5)\end{array}$ & $\begin{array}{l}25.3 \mathrm{a} \\
(1.5)\end{array}$ & $\begin{array}{l}8.1 \mathrm{a} \\
(0.9)\end{array}$ & $\begin{array}{l}1.02 \mathrm{a} \\
(0.55)\end{array}$ & $\begin{array}{l}23.0 \mathrm{a} \\
(3.0)\end{array}$ & $\begin{array}{c}4170 a \\
(72)\end{array}$ \\
\hline Aug. & $\begin{array}{l}46.8 \mathrm{~b} \\
(4.8)\end{array}$ & $\begin{array}{l}4.2 a \\
(0.8)\end{array}$ & $\begin{array}{c}6.2 \mathrm{a} \\
(2.1)\end{array}$ & $\begin{array}{l}18.5 \mathrm{~b} \\
(1.5)\end{array}$ & $\begin{array}{l}5.2 \mathrm{~b} \\
(0.2)\end{array}$ & $\begin{array}{r}0.58 \mathrm{a} \\
(0.09)\end{array}$ & $\begin{array}{l}18.6 \mathrm{a} \\
(4.7)\end{array}$ & $\begin{array}{c}4358 \mathrm{~b} \\
(56)\end{array}$ \\
\hline
\end{tabular}

1Standard deviation.

2Means followed by the same letter are not significantly different at the 0.05 level of probability. 
Table 2. Nutrient composition and cnicin concentrations for spotted knapweed collected in the spring of 1984 and subjected to various solvent extractions.

\begin{tabular}{|c|c|c|c|c|c|c|c|}
\hline \multirow[b]{2}{*}{$\begin{array}{l}\text { Sample } \\
\text { treatment }\end{array}$} & \multicolumn{7}{|c|}{$\%$ Dry Weight } \\
\hline & $\begin{array}{c}\text { Neutral } \\
\text { detergent } \\
\text { fiber }\end{array}$ & $\begin{array}{l}\text { Ether } \\
\text { extract }\end{array}$ & $\begin{array}{c}\text { Crude } \\
\text { protein }\end{array}$ & $\begin{array}{c}\text { Total } \\
\text { nonstructural } \\
\text { carbohydrates }\end{array}$ & Ash & Cnicin & Other \\
\hline \multicolumn{8}{|c|}{$5 \mathrm{~min} . \mathrm{CHCl}_{3}$} \\
\hline Site 1 & 22.6 & 1.9 & 19.5 & 23.5 & 9.8 & $0.00^{1}$ & 22.7 \\
\hline Sites $2-4$ & $\begin{array}{l}28.8 \\
(0.8)\end{array}$ & $\begin{array}{c}2.1 \\
(0.2)\end{array}$ & $\begin{array}{r}9.1 \\
(0.8)\end{array}$ & $\begin{array}{l}25.0 \\
(2.4)\end{array}$ & $\begin{array}{c}8.0 \\
(0.7)\end{array}$ & $\begin{array}{l}0.13 \\
(0.08)\end{array}$ & $\begin{array}{l}26.9 \\
(2.3)\end{array}$ \\
\hline \multicolumn{8}{|l|}{$30 \mathrm{~min} . \mathrm{Et} 0 \mathrm{H}$} \\
\hline Site 1 & 24.2 & 1.9 & 19.4 & 23.1 & 9.6 & 0.11 & 21.7 \\
\hline Sites 2-4 & $\begin{array}{l}28.6 \\
(1.8)\end{array}$ & $\begin{array}{c}2.6 \\
(0.3)\end{array}$ & $\begin{array}{r}9.4 \\
(0.7)\end{array}$ & $\begin{array}{l}25.7 \\
(0.6)\end{array}$ & $\begin{array}{c}8.1 \\
(0.6)\end{array}$ & $\begin{array}{l}0.30 \\
(0.17)\end{array}$ & $\begin{array}{l}25.3 \\
(1.4)\end{array}$ \\
\hline \multicolumn{8}{|c|}{ overnight $\mathrm{H}_{2} \mathrm{O}$} \\
\hline Site 1 & 33.6 & 4.7 & 21.6 & 12.9 & 5.0 & 0.71 & 21.5 \\
\hline Sites 2-4 & $\begin{array}{l}38.9 \\
(2.0)\end{array}$ & $\begin{array}{c}6.0 \\
(0.5)\end{array}$ & $\begin{array}{r}10.9 \\
(0.7)\end{array}$ & $\begin{array}{c}18.8 \\
(3.7)\end{array}$ & $\begin{array}{c}4.5 \\
(0.4)\end{array}$ & $\begin{array}{c}1.30 \\
(0.41)\end{array}$ & $\begin{array}{l}19.8 \\
(3.2)\end{array}$ \\
\hline
\end{tabular}

'Below detection limit.

Table 3. Nutrient composition of spotted knapweed silage cut May and June, and knapweed hay cut Aug. 1984.

\begin{tabular}{|c|c|c|c|c|c|c|c|}
\hline \multirow[b]{2}{*}{$\begin{array}{l}\text { Sample } \\
\text { treatment }\end{array}$} & \multicolumn{7}{|c|}{$\%$ Dry Weight } \\
\hline & $\begin{array}{c}\text { Neutral } \\
\text { detergent } \\
\text { fiber }\end{array}$ & $\begin{array}{c}\text { Ether } \\
\text { extract }\end{array}$ & $\begin{array}{c}\text { Crude } \\
\text { protein }\end{array}$ & $\begin{array}{c}\text { Total } \\
\text { nonstructural } \\
\text { carbohydrates }\end{array}$ & Ash & Cnicin & Other \\
\hline May silage & 23.4 & 4.9 & 19.6 & 9.3 & 10.2 & 0.20 & 32.4 \\
\hline June silage & 30.0 & 3.5 & 16.5 & 11.2 & 8.7 & 0.32 & 29.8 \\
\hline Aug. hay & 56.1 & 1.8 & 5.7 & 11.0 & 4.2 & 0.23 & 21.0 \\
\hline Alfalfa silage ${ }^{1}$ & 52.3 & 3.7 & 17.3 & - & 8.9 & - & - \\
\hline Alfalfa hay ${ }^{1}$ & 47.5 & 2.6 & 17.6 & - & 9.0 & - & - \\
\hline
\end{tabular}

'Ensminger and Olentine 1978.

protein content. It should be noted that the objective for cutting these plants was to prevent seed dispersal and not to make hay, consequently it was cut after its nutritional prime. A higher quality hay could have been obtained by cutting earlier in the season.

In 1985 the knapweed plants were sampled in the bud stage just prior to flowering. Tall and short plants differed in their nutrient composition (Table 4). Tall plants contained significantly more fiber, but less ether extract, carbohydrates, and unknown or other substances. Crude protein did not differ between tall and short plants and there was no consistent trends for ash or gross energy. Tall plants had a slightly lower mineral content for all elements except $\mathrm{K}$, with $\mathrm{Ca}, \mathrm{Al}$, and $\mathrm{Si}$ being significantly lower (Table 5). In vitro dry matter digestibility was acceptable at $56.6 \%$ when averaged for all populations. The tall plants were consistently less digestible (54.6\%) than the short plants $(58.5 \%)$. The 1985 samples had a composition similar to those in 1984.

\section{Discussion}

The forage value of spotted knapweed for livestock has been considered minimal because of poor nutritive quality and high fiber content (Watson and Renney 1974, Maddox 1979). Our analysis indicates that spotted knapweed is not lacking in nutritional quality during the spring, when livestock are most willing to graze it (Cox 1983, Spoon et al. 1983).

Table 4. Nutrient composition of tall and short spotted knapweed plants collected at 7 locations in western Montana during summer, 1985.

\begin{tabular}{|c|c|c|c|c|c|c|c|c|c|c|}
\hline \multirow{3}{*}{$\begin{array}{l}\text { Plant } \\
\text { size }\end{array}$} & \multirow{2}{*}{\multicolumn{2}{|c|}{$\begin{array}{c}\text { Stem length } \\
\text { (centimeters) }\end{array}$}} & \multicolumn{7}{|c|}{$\%$ Dry Weight } & \multirow{3}{*}{$\begin{array}{l}\text { Gross } \\
\text { energy } \\
\text { (cal/g) }\end{array}$} \\
\hline & & & \multirow{2}{*}{$\begin{array}{c}\text { Neutral } \\
\text { detergent } \\
\text { fiber }\end{array}$} & \multirow{2}{*}{$\begin{array}{l}\text { Ether } \\
\text { extract }\end{array}$} & \multirow{2}{*}{$\begin{array}{l}\text { Crude } \\
\text { protein }\end{array}$} & \multirow[b]{2}{*}{$\mathrm{TNC}^{1}$} & \multirow[b]{2}{*}{ Ash } & \multirow[b]{2}{*}{ Other } & \multirow{2}{*}{$\begin{array}{l}\text { Digest- } \\
\text { ibifity }\end{array}$} & \\
\hline & Mean & Range & & & & & & & & \\
\hline Tall & $\begin{array}{l}93 a^{2} \\
(12)^{3}\end{array}$ & $\begin{array}{c}36-134 \\
(14)(15)\end{array}$ & $\begin{array}{l}50.6 \mathrm{a} \\
(2.2)\end{array}$ & $\begin{array}{l}4.6 \mathrm{a} \\
(1.4)\end{array}$ & $\begin{array}{c}9.9 \mathrm{a} \\
(1.8)\end{array}$ & $\begin{array}{l}13.1 \mathrm{a} \\
(1.7)\end{array}$ & $\begin{array}{r}6.3 a \\
(0.8)\end{array}$ & $\begin{array}{l}15.4 \mathrm{a} \\
(2.5)\end{array}$ & $\begin{array}{l}54.6 \mathrm{a} \\
(1.0)\end{array}$ & $\begin{array}{c}4318 a \\
(109)\end{array}$ \\
\hline Short & $\begin{array}{r}22 b \\
(5)\end{array}$ & $\begin{array}{c}8-43 \\
(4)(9)\end{array}$ & $\begin{array}{c}36.1 \mathrm{~b} \\
(3.6)\end{array}$ & $\begin{array}{l}7.1 \mathrm{~b} \\
(1.2)\end{array}$ & $\begin{array}{l}8.6 \mathrm{a} \\
(2.3)\end{array}$ & $\begin{array}{c}15.6 \mathrm{~b} \\
(0.8)\end{array}$ & $\begin{array}{l}6.6 \mathrm{a} \\
(1.0)\end{array}$ & $\begin{array}{c}26.0 \mathrm{~b} \\
(4.3)\end{array}$ & $\begin{array}{c}58.5 b \\
(2.2)\end{array}$ & $\begin{array}{r}4369 a \\
(92)\end{array}$ \\
\hline All & $\begin{array}{c}58 \\
(38)\end{array}$ & $\begin{array}{c}22-89 \\
(18)(49)\end{array}$ & $\begin{array}{l}43.3 \\
(8.0)\end{array}$ & $\begin{array}{l}5.9 \\
(1.8)\end{array}$ & $\begin{array}{l}9.2 \\
(2.1)\end{array}$ & $\begin{array}{l}14.4 \\
(1.8)\end{array}$ & $\begin{array}{l}6.5 \\
(0.9)\end{array}$ & $\begin{array}{l}20.7 \\
(6.5)\end{array}$ & $\begin{array}{l}56.6 \\
(2.6)\end{array}$ & $\begin{array}{l}4344 \\
(100)\end{array}$ \\
\hline
\end{tabular}

ITotal nonstructural carbohydrates.

2Means followed by the same letter are not significantly different at the 0.05 level of probability.

standard deviation. 
Table 5. The mineral composition of tall and short spotted knapweed plants collected at seven locations in western Montana during summer, 1985.

\begin{tabular}{|c|c|c|c|c|c|c|c|c|c|c|c|c|c|c|}
\hline \multirow[b]{2}{*}{ Plant size } & \multicolumn{4}{|c|}{ \% Dry Weight } & \multicolumn{10}{|c|}{ Ppm $^{1}$} \\
\hline & $\mathrm{Ca}$ & $\mathbf{M g}$ & $\mathbf{P}$ & $\mathbf{K}$ & Al & B & $\mathrm{Cu}$ & $\mathrm{Fe}$ & $\mathrm{Mn}$ & Mo & $\mathrm{Si}$ & $\mathrm{Na}$ & $\mathrm{Ti}$ & $\mathrm{Zn}$ \\
\hline Tall & $\begin{array}{l}0.84 a^{2} \\
(0.17)^{3}\end{array}$ & $\begin{array}{l}0.14 \mathrm{a} \\
(0.04)\end{array}$ & $\begin{array}{l}0.17 \mathrm{a} \\
(0.04)\end{array}$ & $\begin{array}{l}2.18 \mathrm{a} \\
(0.27)\end{array}$ & $\begin{array}{l}92 \mathrm{a} \\
(35)\end{array}$ & $\begin{array}{l}28.0 \mathrm{a} \\
(15.4)\end{array}$ & $\begin{array}{l}7.0 \mathrm{a} \\
(2.1)\end{array}$ & $\begin{array}{l}121.5 a \\
(41.9)\end{array}$ & $\begin{array}{r}19.1 \mathrm{a} \\
(5.1)\end{array}$ & $\begin{array}{l}0.4 \mathrm{a} \\
(0.2)\end{array}$ & $\begin{array}{r}318 \mathrm{a} \\
(60)\end{array}$ & $\begin{array}{r}17 \mathrm{a} \\
(8)\end{array}$ & $\begin{array}{l}4.0 \mathrm{a} \\
(2.0)\end{array}$ & $\begin{array}{l}13.5 \mathrm{a} \\
(2.0)\end{array}$ \\
\hline Short & $\begin{array}{l}1.13 \mathrm{~b} \\
(0.17)\end{array}$ & $\begin{array}{l}0.18 \mathrm{a} \\
(0.04)\end{array}$ & $\begin{array}{l}0.21 \mathrm{a} \\
(0.04)\end{array}$ & $\begin{array}{c}1.88 \mathrm{a} \\
(0.34)\end{array}$ & $\begin{array}{l}165 b \\
(89)\end{array}$ & $\begin{array}{l}29.7 \mathrm{a} \\
(15.9)\end{array}$ & $\begin{array}{l}8.3 \mathrm{a} \\
(4.8)\end{array}$ & $\begin{array}{l}183.4 \mathrm{a} \\
(81.4)\end{array}$ & $\begin{array}{l}48.9 \mathrm{a} \\
(36.8)\end{array}$ & $\begin{array}{l}1.2 \mathrm{a} \\
(1.0)\end{array}$ & $\begin{array}{l}457 \mathrm{~b} \\
(138)\end{array}$ & $\begin{array}{l}25 a \\
(14)\end{array}$ & $\begin{array}{l}7.8 \mathrm{a} \\
(5.0)\end{array}$ & $\begin{array}{l}15.9 \mathrm{a} \\
(5.1)\end{array}$ \\
\hline All & $\begin{array}{l}0.99 \\
(0.22)\end{array}$ & $\begin{array}{l}0.16 \\
(0.04)\end{array}$ & $\begin{array}{l}0.19 \\
(0.04)\end{array}$ & $\begin{array}{l}2.03 \\
(0.34)\end{array}$ & $\begin{array}{l}128 \\
(75)\end{array}$ & $\begin{array}{l}28.8 \\
(15.1)\end{array}$ & $\begin{array}{l}7.6 \\
(3.6)\end{array}$ & $\begin{array}{l}152.5 \\
(70.0)\end{array}$ & $\begin{array}{l}34.0 \\
(29.6)\end{array}$ & $\begin{array}{c}0.8 \\
(0.8)\end{array}$ & $\begin{array}{l}388 \\
(125)\end{array}$ & $\begin{array}{l}21 \\
(12)\end{array}$ & $\begin{array}{l}5.9 \\
(4.2)\end{array}$ & $\begin{array}{l}14.7 \\
(3.9)\end{array}$ \\
\hline
\end{tabular}

$\mathrm{Cd}, \mathrm{Co}$, and $\mathrm{Hg}$ averaged less than $1.0 \mathrm{ppm}$ in both tall and short plants.

${ }^{2}$ Means followed by the same letter are not significantly different at the 0.05 level of probability.

'Standard deviation.

Tall plants had significantly more fiber and less ether extract, nonstructural carbohydrates and miscellaneous components (Table 4). There was no difference between tall and short plants for crude protein, ash, or gross energy. Mineral content and digestibility were lower in the tall plants (Table 5), but the differences are of no major consequence.

The leaves of spotted knapweed contain the bitter tasting sesquiterpene lactone, cnicin, (Politis 1946a, Politis 1946b, Wagner 1977, Muir and Majak 1983, Locken and Kelsey in press, Kelsey and Locken 1987) that could decrease palatability relative to other plants. In the combined aerial tissues cnicin concentrations are lowest in the spring $(0.5 \%$ dry wt.) and reach a maximum (1.0\%) around flowering in July (Locken and Kelsey in press). Interestingly, the flower heads of knapweed contain only trace quantities of cnicin, and these structures are selectively eaten by most livestock and wildlife (Watson and Renney 1974, Spoon et all. 1983, Bucher 19j84). Bitter tasting lactones in other plant species inhibit feeding by mammalian herbivores (Burnett et al. 1977, 1978; Mabry and Gill 1979). Sesquiterpene lactones in Russian knapweed (C. repens $\mathrm{L}$.) and yellow star thistle (C. solstitialis $\mathrm{L}$.) are the suspected cause of equine nigropallidal encephalomalacia in horses that have ingested large quantities of these plants for prolonged periods (Cordy 1978, Stevens 1982, Stevens and Merrill 1985). To our knowledge there have been no reports of any livestock poisoning from spotted knapweed in Montana or Canada (Watson and Renney 1974).

Cnicin concentrations in fresh or dry spotted knapweed tissues can be greatly reduced by extraction for short periods with organic solvents without damaging the nutritional composition of the extracted residue (Tables 1 and 2). Water extraction removed carbohydrates and minerals, concentrating the cnicin, crude protein, and fiber in the residue. Ensilaging decreased the cnicin concentration by about 50\% (Tables 1 and 3). Plants that had regrown after cutting also had a lower cnicin content (Table 1). Except for ensilaging, any treatment to remove cnicin would be expensive and probably unnecessary since animals have been observed eating immature plants, knapweed silage, and hay.

Our data indicate there is certainly no nutritional reason to restrict animals'consumption of spotted knapweed prior to flowering. Grazing should be encouraged, because it not only reduces forage loss, but can simultaneously decrease knapweed's size and seed production (authors' personal observations). Cox (1983) has reported near elimination of knapweed seed production on pastures once densely covered with knapweed, and the associated grasses have not been overgrazed in the process. This was achieved by allowing the sheep to selectively graze the knapweed in the spring and early summer, then removing them before they heavily grazed the grasses. A second grazing period was required in August to remove the knapweed regrowth (Cox, personal communication). We examined Cox's pastures in September, after a summer of sheep grazing, and found small plants with only a few flowers being produced. The impact of grazing on spotted knapweed needs to be quantified with controlled experiments.
Observations indicate that livestock will eat knapweed silage and hay during winter. In a preliminary experiment the silage prepared in this study was fed to 2 cows in December 1984. Initially they were offered a choice of knapweed silage, and hay with some silage mixed in. By the fourth day both animals were freely eating the silage. In another preliminary trial, a farm flock of Suffolk ewes ate the silage, in place of hay, when offered the first day. At a later date they also ate, without hesitation, the unused portions of the knapweed hay sampled for analysis (Table 3 ). Local individuals have provided additional observations of knapweed being used as forage. A dairyman reported that his cows like fresh chopped knapweed prior to bloom, and grass/knapweed silage caused no changes in milk production. Dried knapweed has been fed to goats in large quantities during winter without ill effects (Gisselbeck, personal communication). There were also reports that the knapweed hay we analyzed was being fed to cattle. Although further research is essential to measure animal performance, these observations do indicate that most livestock will eat knapweed silage and hay during the winter.

Cutting knapweed prior to flowering should produce a nutritionally acceptable silage or hay and there will be no seeds. Hay containing knapweed could be certified as seed free if cut prior to flowering, but to avoid accidental spread it should be used on site, or confined within infested areas. Harvesting knapweed can also impact its seed production. Watson and Renney (1974) found that a single mowing at bud, or flowering, stages greatly reduced the number of seed-producing plants, and decreased the viability of the seeds that formed.

We want to emphasize that being able to utilize spotted knapweed as forage or feed for livestock does not make the plant desirable; it is still noxious, and should be treated as such. Grazing or harvesting knapweed for forage may provide an economically acceptable method of managing the plants because it can reduce plant size and decrease seed production. It can also be implemented immediately with minimal costs to most land owners. Utilization is not a solution, but an alternative that may be used by some individuals, where feasible, until economically acceptable controls can be developed.

\section{Literature Cited}

Bucher, R.F. 1984. The potential cost of spotted knapweed to Montana range users. Montana State Univ., Coop. Ext. Serv. Bull. 1316.

Burnett, W.C., S.B. Jones, and T.J. Mabry. 1977. Evolutionary implications of sesquiterpene lactones in Vernonia (Compositae) and mammalian herbivores. Taxon 26:203-207.

Burnett, W.C., Jr., S.B. Jones, Jr., and T.J. Mabry. 1978. The role of sesquiterpene lactones in plant-animal coevolution, p. 233-257. In: J.B. Harborne (ed.), Biochemical aspects of plant and animal coevolution. Academic Press, London.

Cordy, D.R. 1978. Centaurea species and equine nigropallidal encephalomalacia, p. 327-336. In: R.F. Keeler, K.R. Van Kampen, and L.F. James (eds.), Effects of poisonous plants on livestock. Academic Press, New York. 
Cox, J.W. 1983. Try sheep to control spotted knapweed. Montana FarmerStockman 70:64-65.

deSilveirn, A.J., F.F.F. Teles, and J.W. Stull. 1978. A rapid technique for total nonstructural carbohydrate determination of plant tissue. J. Agr. Food Chem. 26:770-772.

Ensminger, M.E., and C.G. Olentine, Jr. 1978. Feeds \& nutritioncomplete. The Ensminger Publishing Co., Clovis, Calif.

French, R.A., and Lacey, J.R. 1983. Knapweed: Its cause, effect and spread in Montana. Montana State Univ., Coop. Ext. Serv. Cir. 307.

Goering, H.K., and P.J. Van Soest. 1970. Forage fiber analysis. Agr. Handb. No. 379, USDA. U.S. Government Printing Office, Washington, D.C.

Harris, L.E. 1970. Nutrition research techniques for domestic and wild animals. L.E. Harris, Logan, Utah.

Harris, P., and R. Cranston. 1979. An economic evaluation of control methods for diffuse and spotted knapweed in western Canada. Can. J. Plant Sci. 59:375-382.

Kelsey, R.G., and L.J. Locken. (1987). Phytotoxic properties of cnicin, a sesquiterpene lactone from Centaurea maculosa (spotted knapweed). J. Chem. Ecol. 13:19-33.

Lacey, J.R. 1983. A complete takeover by knapweed in 2001? Montana Farmer-Stockman 70c:32-34.

Locken, L.J., and R.G. Kelsey. (In Press). Cnicin concentrations in Centaurea maculosa, spotted knapweed. Biochem. Syst. Ecol.

Mabry, T.J., and J.E. Gill. 1979. Sesquiterpene lactones and other terpenoids, p. 501-537. In: G.A. Rosenthal, and D.H. Janzen (eds.), Herbivores: Their interaction with secondary plant metabolites. Academic Press, New York.

Maddox, D.M. 1979. The knapweeds: Their economic and biological control in the western states, U.S.A. Rangelands 1:139-141.
Marchand, B., H.M. Behl, and E. Rodriguez. 1983. Application of highperformance liquid chromatography for analysis and isolation of sesquiterpene lactones. J. Chromatography 265:97-104.

Moore, R.J. 1972. Distribution of native and introduced knapweeds (Centaurea) in Canada and the United States. Rhodora 74:331-346.

Muir, A.D., and W. Majak. 1983. Allelopathic potential of diffuse knapweed (Centaurea diffusa) extracts. Can. J. Plant Sci. 63:989-996.

Politis, J. 1946a. Sur la formation des glucosides amers dans les poils glanduleux de certaines plantes. C.R. Acad. Sci. (Paris) 222:910-911.

Politis, J. 1946b. Sur le mode de formation des essences dans certains poils glanduleux. C.R. Acad. Sci. (Paris) 222:1244-1245.

Reed, C.F., and R.O. Hughes. 1970. Selected weeds of the United States, p. 382-383. Agr. Handb. No. 366, USDA. U.S. Government Printing Office, Washington, D.C.

Spoon, C.W.,H.R. Bowles, and A. Kulla. 1983. Noxious weeds on the Lolo National Forest. USDA Forest Serv., Northern Region, situation analysis staff paper, Missoula.

Stevens, K.L. 1982. Sesquiterpene lactones from Centaurea repens. Phytochemistry 21:1093-1098.

Stevens, K.L., and G.B. Merrill. 1985. Sesquiterpene lactones and allelochemicals from Centaurea species, p. 83-98. In: A.C. Thompson (ed.), The chemistry of allelopathy, ACS Symposium Series No. 268. American Chemical Society, Washington, D.C.

Strang, R.M., K.M. Lindsay, R.S. Price. 1979. Knapweeds: British Columbia's undesirable aliens. Rangelands 1:141-143.

Wagner, H. 1977. Pharmaceutical and economic uses of the Compositae, p. 411-433. In: V.H. Heywood, J.B. Harborne, and B.L. Turner (eds.), The biology and chemistry of the Compositae, Vol. 1. Academic Press, London.

Watson, A.K., and A.J. Renney. 1974. The biology of Canadian weeds. 6. Centaurea diffusa and C. maculosa. Can. J. Plant Sci. 54:687-701. 